\title{
STUDIES IN PREMATURITY. PART 4 \\ DEVELOPMENT AND PROGRESS OF THE PREMATURELY BORN CHILd IN THE PRESCHOOL PERIOD
}

\author{
BY \\ CECIL MARY DRILLIEN, M.B., Ch.B., D.C.H. \\ (From the Department of Child Life and Health, University of Edinburgh*)
}

The previous papers in this series (Drillien, 1947) contain a detailed analysis and discussion of the etiology of prematurity, stillbirth, and infant death occurring in the Simpson Memorial Pavilion, Edinburgh, during the years 1943 to 1945 inclusive, a random 1 in 10 sample of full-term surviving infants born during the same period serving as a control. The present paper deals with the progress of the surviving premature infants included in the population studied. The first section gives a comparison of the medical history of premature and full-term babies before discharge from hospital, and the second section an account of a follow-up examination of a sample of the premature infants, now aged between one-and-a-half and four-and-a-half years, and of a control group of full-term children.

\section{Section 1: Progress in Hospital}

Infection rates in premature and mature infants. During the period under review the minimum length of stay in hospital for normal mothers and infants was ten days. Premature infants usually remained in hospital for much longer, but in order to compare infection rates in infants of different birth weights, only those cases of infection occurring within ten days of birth have been included. Infections occurring in infants who subsequently died in hospital have been dealt with in Part 3 (Drillien, 1947) and are not considered here. Twins have been excluded. Data were obtained from paediatric records of all the surviving premature infants, and one in ten of the surviving full-term infants.

The infections recorded were: (1) thrush; (2) septic skin infections, mainly staphylococcal; (3) discharging eyes, excluding.those cases resulting from instillation of silver nitrate solution; and (4) diarrhoea, with or without vomiting, excluding those cases considered to be due solely to dietary disturbance.

Table 1 gives the percentage of infants contracting one or more of the above infections during the first

* During the tenure or a Streatfield Research Scholarship of the Royal College of Physicians of London and the Royal Colleze of Surgeons of Engiand. ten days of life. It will be seen that in the smallest weight group nearly one in three of those who survived contracted a minor infection, compared with one in sixteen of the mature infants. The infection rate falls steadily with increasing birth weight in the premature group, but after a birth weight of $5.5 \mathrm{lb}$. has been reached the infection rate remains steady at about 6 per cent. These differences between weight groups are highly significant, the chi-squared value being $31 \cdot 20$.

Table 2 gives the morbidity rate for each of the four infections mentioned according to birth weight. This shows that though the smallest infants have a much higher incidence of all infections except gastro-enteritis, birth weight when it is over $3.5 \mathrm{lb}$. does not appear to have a marked effect on infection rate except for thrush. This is demonstrated in fig. 1, where the average morbidity rate for each infection is taken to be 100 , and the variations from this mean have been calculated for each weight group.

The higher incidence of thrush among premature infants is probably accounted for by the greater proportion of bottle-fed infants. Henderson (1943) in an investigation into the incidence of thrush in the Simpson Memorial Pavilion, found no striking difference between the incidence of thrush in bottlefed infants, whether premature or mature.

It does seem, however, that the very smallest infants are particularly susceptible to septic infections, as shown by the high incidence of septic skin infections and discharging eyes. No cases of gastro-enteritis occurred in the smallest group in the first ten days, and very few cases in the 3.5 to 4.5 lb. group, though the largest premature infants had a much higher rate than the mature babies.

\section{TABLE 1}

MINOR INFECTIONS OCCURRING WITHIN THE FIRST TEN DAYS OF LIFE

\begin{tabular}{|c|c|c|c|}
\hline Birth weight & & $\begin{array}{l}\text { No. of } \\
\text { infants }\end{array}$ & $\begin{array}{l}\text { Per cent. } \\
\text { infected }\end{array}$ \\
\hline $\begin{array}{l}2 \mathrm{lb} .9 \mathrm{oz} \text { to } 3 \mathrm{lb} .8 \mathrm{oz} \\
3 \mathrm{lb} .9 \mathrm{oz} \text { to } 4 \mathrm{lb} .8 \mathrm{oz} \text {. } \\
4 \mathrm{lb} 9 \mathrm{oz} \text { to } 5 \mathrm{lb} .8 \mathrm{oz} \text {. } \\
5 \mathrm{lb} 9 \mathrm{oz} \text { to } 10 \mathrm{lb} \text {. }\end{array}$ & $\begin{array}{l}\cdots \\
\cdots \\
\cdots\end{array}$ & $\begin{array}{r}29 \\
124 \\
277 \\
576\end{array}$ & $\begin{array}{r}31 \cdot 0 \\
13 \cdot 7 \\
9 \cdot 8 \\
6 \cdot 0\end{array}$ \\
\hline
\end{tabular}


TABLE 2

SPECIFIC INFECTIONS OCCURRING WITHIN THE FIRST TEN DAYS OF LIFE

\begin{tabular}{|c|c|c|c|c|c|c|}
\hline \multirow{2}{*}{ Birth weight } & & & \multicolumn{4}{|c|}{ Incidence of cases of: } \\
\hline & & & Thrush & Septic skin infection & Conjunctivitis & Gastro-enteritis \\
\hline $\begin{array}{l}2 \mathrm{lb} .9 \mathrm{oz} \text { to } 3 \mathrm{lb} .8 \mathrm{oz} . \\
3 \mathrm{lb} .9 \mathrm{oz} \text { to } 4 \mathrm{lb} .8 \mathrm{oz} . \\
4 \mathrm{lb} .9 \mathrm{oz} \text { to } 5 \mathrm{lb} .8 \mathrm{oz} . \\
5 \mathrm{lb} .9 \mathrm{oz} \text { to } 10 \mathrm{lb} .0 \mathrm{oz} .\end{array}$ & $\begin{array}{l}\cdots \\
\cdots \\
\cdots \\
\cdots\end{array}$ & $\begin{array}{l}\cdots \\
\cdots \\
\cdots\end{array}$ & $\begin{array}{r}17 \cdot 2 \\
6 \cdot 5 \\
2 \cdot 9 \\
1 \cdot 9\end{array}$ & $\begin{array}{r}13 \cdot 8 \\
4 \cdot 8 \\
2 \cdot 5 \\
3 \cdot 8\end{array}$ & $\begin{array}{l}6 \cdot 9 \\
0 \cdot 8 \\
1 \cdot 8 \\
1 \cdot 2\end{array}$ & $\begin{array}{l}-1 \cdot 6 \\
3 \cdot 3 \\
0 \cdot 5\end{array}$ \\
\hline Average incidence in total sa & & & $2 \cdot 8$ & $3 \cdot 5$ & $1 \cdot 3$ & $1 \cdot 2$ \\
\hline
\end{tabular}

It seems reasonable to assume from this that smaller infants are more susceptible to gastroenteritis if they come into contact with the infection. Infants under $4.5 \mathrm{lb}$. would almost certainly have been isolated in an incubator room for the first ten days, under ideal nursing conditions, whereas those over $4.5 \mathrm{lb}$. whose general condition was good would probably have been nursed alongside the mature infants in the main nursery.

Pathological conditions other than infections, cccurring in the first ten days of life. Other pathological conditions occurring within the first few days of life were: (1) cyanotic attacks; (2) severe jaundice with oedema; (3) haemorrhagic disease; (4) cerebral signs, such as anxiety and restlessness and localized twitching or generalized convulsion, with or without respiratory and cardiac symptoms; and (5) dehydration fever, that is, a rise of temperature to $100^{\circ} \mathrm{F}$., with loss of weight, there being no obvious signs of infection or other abnormality present. Again only infants surviving their discharge have been included. Table 3 gives the incidence of these conditions in premature and mature infants.

\section{Section 2: Progress in Early Childhood}

In order to trace the subsequent history of infants included in the survey, a follow-up clinic was held in 1947. Every married mother of a surviving infant who gave an Edinburgh address was written to and asked to attend this special clinic. Altogether 430 full-term and 285 premature infants were written for. The response was about 40 per cent. in each case. It was decided after the conclusion of the follow-up not to include the twins, about thirty in all, as their number was not large enough to constitute a separate group. The following sections are based on the history and examination of 277 children, 103 of them prematurely born, and 174 full-term children.

It is unlikely that this sample is a random one, there being two obvious sources of bias. First, those children whose progress was not satisfactory would be the more likely to attend, and secondly the more conscientious mothers would tend to bring their children back. But as the main purpose of the enquiry is a .comparison between two groups, in both of which these sources of bias would operate, and as there is no attempt to draw conclusions applicable to the general population, the bias can be ignored.

A more serious source of error occurs because it was impossible to determine how many children had died after discharge from hospital. The Edinburgh Corporation Maternity and Child Welfare Department keeps a record of all deaths under one year of age occurring in the city, and the names of all children written for were checked against this record. In addition a number of mothers wrote to say that their children had died.

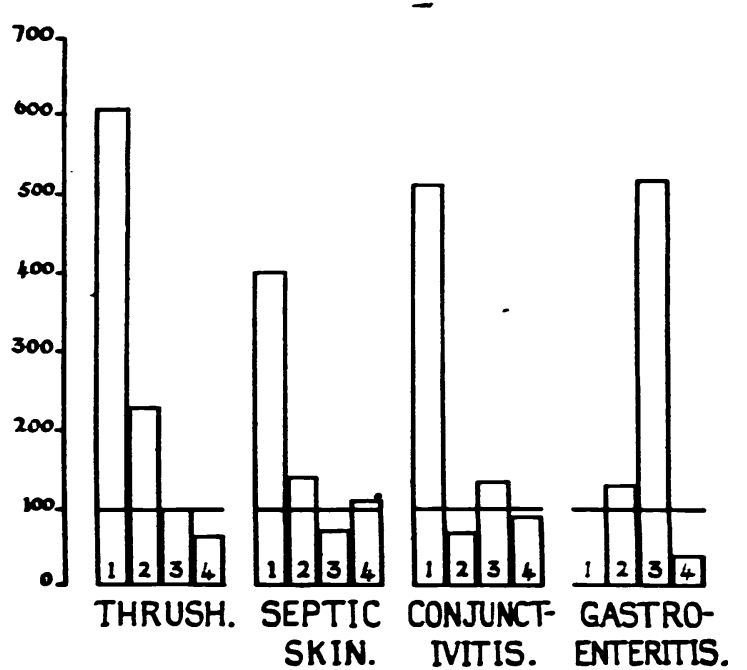

FIG. 1.-Relative infection rates in the first ten days of life, according to weight at birth; average rate of each infection being taken as 100 .

Birth weight groups: (1) $2 \mathrm{lb} .9 \mathrm{oz}$ to $3 \mathrm{lb} .8 \mathrm{oz}$; (2) $3 \mathrm{lb} .9 \mathrm{oz}$ to $4 \mathrm{lb} .8 \mathrm{oz}$; (3) $4 \mathrm{lb} .9 \mathrm{oz}$ to $5 \mathrm{lb} .8 \mathrm{oz}$; (4) $5 \mathrm{lb} 9 \mathrm{oz}$ to $10 \mathrm{lb}$. 
TABLE 3 OTHER PATHOLOGICAL CONDITIONS OCCURRING WITHIN THE FIRST TEN DAYS OF LIFE

\begin{tabular}{|c|c|c|c|c|c|}
\hline $\begin{array}{c}\text { Birth weight } \\
.\end{array}$ & Cyanotic attacks & Cerebral signs & Jaundice & $\begin{array}{c}\text { Haemorrhagic } \\
\text { disease }\end{array}$ & $\begin{array}{c}\text { Dehydration } \\
\text { fever }\end{array}$ \\
\hline $\begin{array}{l}4 \mathrm{lb} .8 \mathrm{oz} \text {. and under } \\
4 \mathrm{lb} .9 \mathrm{oz} \text {. to } 5 \mathrm{lb} .8 \mathrm{oz} \text {. } \\
5 \mathrm{lb} .9 \mathrm{oz} \text {. and over }\end{array}$ & $\begin{array}{l}9 \cdot 8 \\
3 \cdot 3 \\
0 \cdot 2\end{array}$ & $\begin{array}{l}\overline{2 \cdot 2} \\
3 \cdot 3\end{array}$ & $\begin{array}{l}2 \cdot 0 \\
1 \cdot 4 \\
-\end{array}$ & $\begin{array}{l}2 \cdot 0 \\
0 \cdot 7 \\
-\end{array}$ & $\overline{1}$ \\
\hline
\end{tabular}

The number of deaths ascertained was seventeen out of the premature group ( 6 per cent. of those written for), and seven of the full-term group ( 1.6 per cent.). Although the figures are incomplete, it is certain that the number of deaths of prematurely born children surviving their discharge from hospital greatly exceeds that of full-term children.

Table 4 gives the age composition of the children attending the clinic.

A full history was taken from the mother as to the following: (1) method of feeding, from birth to weaning; (2) administration of vitamin supplements; (3) attendance at welfare clinics; (4) diphtheria immunization; (5) age at which the child sat, stood, walked, and talked; (6) infections, and other illnesses or abnormalities suffered by the child; (7) behaviour disorders; (8) housing conditions. A physical examination was also made. -

Method of feeding. The following questions were put to each mother at the interview: (1) For how long did total and partial breast feeding continue ? (2) In cases of failure to breast feed, to what cause did she attribute the failure? (3) In changing from breast to bottle feeding, what was the artificial food chosen, and on whose advice ?

Infants were classified into five groups: those who were (1) never totally breast-fed, including cases where breast feeding continued for less than one week; (2) fully breast-fed for longer than one week but less than one month; (3) fully breast-fed longer than one, but less than three months; (4) fully breast-fed for longer than three months, but transferred wholly on to the bottle before the institution of mixed feeding; (5) fully breast-fed until weaning on to solid food, including those who after mixed feeding was started were taken off the breast, and given one, or at the most two bottles daily.

It will be seen from table 5 and fig. 2 that success in breast feeding depends largely on the birth weight of the infant. In over three-quarters of the smallest premature infants breast feeding was never attempted, while in the mature group nearly half the mothers fed their babies for longer than three months.
BREAST FEEDING IN PRIMIPARAE AND MULTIPARAE. Figs. 3 and 4 demonstrate the duration of breast feeding in primiparae and multiparae. With both premature and mature infants multiparae are more successful in breast feeding.

In the case of premature births an equal proportion of primiparae and multiparae begin by breast feeding, but the proportion of the former who continue to do so after discharge from hospital falls steadily below that of the multiparae. With mature infants the multiparae show a higher percentage of successful nursing right from the beginning. This is in spite of the fact that there will be a larger number of healthy mothers of first babies, multiparae only being admitted in event of some complication of pregnancy or delivery, or for social reasons.

CAUSES OF FAILURE TO BREAST FEED. The following reasons were given by mothers for failure in nursing: (1) insufficient lactation (the mother stated that the baby was dissatisfied, hungry, and failed to gain weight); (2) illness of the mother herself (either her condition after delivery was so poor that nursing was not allowed, or else after a successful period of breast feeding she became ill and feeding had to be abandoned); (3) prematurity of the baby (the baby was too small to be allowed to suck at the breast, and it proved impossible to keep up the milk supply by expression); (4) difficulty in getting the

$$
\text { TABLE } 4
$$

AGE COMPOSITION OF PREMATURE AND MATURE CHILDREN ATTENDING FOLLOW-UP CLINIC

\begin{tabular}{|c|c|c|}
\hline & \multicolumn{2}{|c|}{ No. of children } \\
\hline & Premature & Mature \\
\hline $\begin{array}{l}1 \text { yr. } 6 \text { mos. and under } \\
1 \text { yr. } 7 \text { mos. to } 2 \text { yrs. } \\
2 \text { yrs. } 1 \text { mo. to } 2 \text { yrs. } 6 \text { mos. } \\
2 \text { yrs. } 7 \text { mos. to } 3 \text { yrs. } \\
3 \text { yrs. } 1 \text { mo. to } 3 \text { yrs. } 6 \text { mos. } \\
3 \text { yrs. } 7 \text { mos. to } 4 \text { yrs. } \\
4 \text { yrs. } 1 \text { mo. to } 4 \text { yrs. } 6 \text { mos. } \\
4 \text { yrs. } 7 \text { mos. and over }\end{array}$ & $\begin{array}{r}-11 \\
22 \\
20 \\
8 \\
15 \\
25 \\
2\end{array}$ & $\begin{array}{r}7 \\
26 \\
19 \\
44 \\
26 \\
37 \\
14 \\
1\end{array}$ \\
\hline Total ... & 103 & 174 \\
\hline
\end{tabular}


baby to fix (these infants were all premature but lusty enough to be put to the breast); (5) breast abscess; (6) retracted nipples; (7) other reasons.

Table 6 gives the causes of failure to breast feed premature and mature infants. In both groups insufficient lactation was the commonest cause. Breast abscess occurred much more commonly in the mature group.

TABLE 5

DURATION OF BREAST FEEDING ACCORDING TO BIRTH WEIGHT OF INFANT

\begin{tabular}{|c|c|c|c|}
\hline \multirow{2}{*}{$\begin{array}{l}\text { Duration of } \\
\text { breast feeding }\end{array}$} & \multicolumn{3}{|c|}{ Birth weight } \\
\hline & $\begin{array}{l}4 \mathrm{lb} .8 \mathrm{oz} \text {. } \\
\text { and under }\end{array}$ & $\begin{array}{c}4 \mathrm{lb} .9 \mathrm{oz} \text {. to } \\
5 \mathrm{lb} .8 \mathrm{oz} \text {. }\end{array}$ & $\begin{array}{l}5 \mathrm{lb} .9 \mathrm{oz} . \\
\text { and over }\end{array}$ \\
\hline $\begin{array}{l}\text { Never } \\
\text { Less than } 1 \text { month } \\
\text { Less than } 3 \\
\text { months } \\
3 \text { months-wean- } \\
\text { ing ... } \\
\text { Fully breast-fed }\end{array}$ & $\begin{array}{r}76 \cdot 0 \\
4 \cdot 0 \\
8 \cdot 0\end{array}$ & $\begin{array}{r}35 \cdot 9 \\
12 \cdot 8 \\
9 \cdot 0 \\
12 \cdot 8 \\
20 \cdot 5\end{array}$ & $\begin{array}{l}14 \cdot 4 \\
18 \cdot 4 \\
18 \cdot 4 \\
10 \cdot 3 \\
38 \cdot 5\end{array}$ \\
\hline Total & $100 \cdot 0$ & $100 \cdot 0$ & $100 \cdot 0$ \\
\hline No. of cases & 25 & 78 & 174 \\
\hline
\end{tabular}

Fig. 5 demonstrates at what stage in feeding these difficulties arise. In the premature group failure to attempt nursing was due to the prematurity of the infant in about 60 per cent. of the failures. Once feeding had been successfully established, the
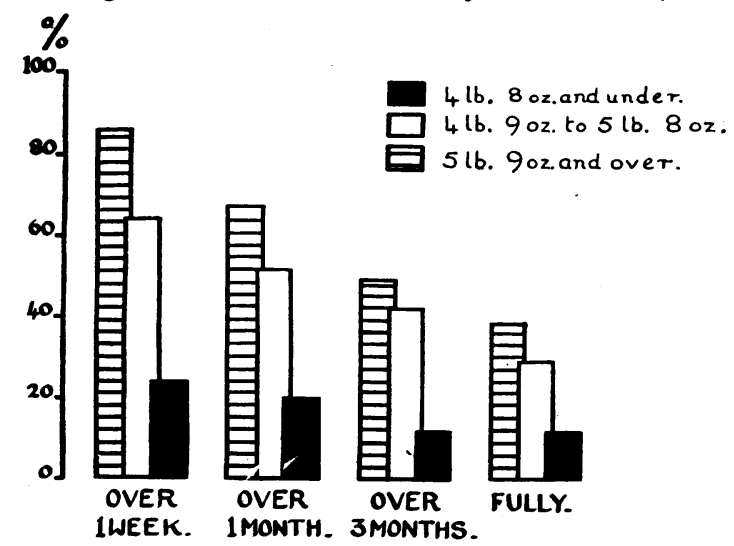

FIG. 2.-Duration of breast feeding according to birth weight.

commonest cause of subsequent failure was insufficient lactation, this being the commonest cause of failure at every stage in the mature group.

In the British Paediatric Association survey of breast feeding in Birmingham (Neale and others,
1943), causes of failure were given as follows: anxiety of mother re progress of infant, 33 per cent.; illness of mother, 23 per cent.; mother returning to work, 15 per cent.; other reasons, 29 per cent.

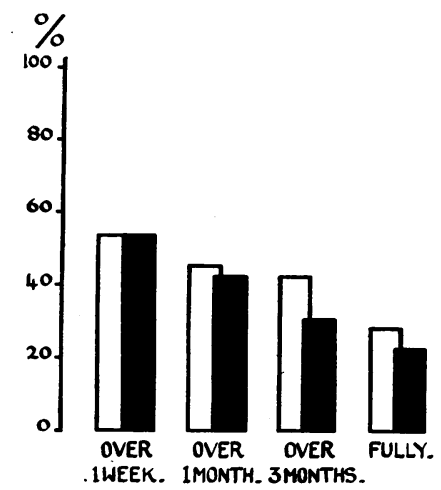

FIG. 3.-Duration of breast feeding of premature infants by primiparae and multiparae. Outlined rectangles, multiparae.

Black ,", primiparae.

Artificial feeding. The artificial foods chosen as a substitute for breast feeding were classified as follows: (1) fresh milk; (2) national dried milk; (3) a proprietary dried milk preparation; (4) additions to fresh or dried milk, other than sugar, vitamin supplements, Virol, or mineral salts. The commonest addition was Sister Laura's food; others were Benger's food, oat flour, patent barley, and groats.

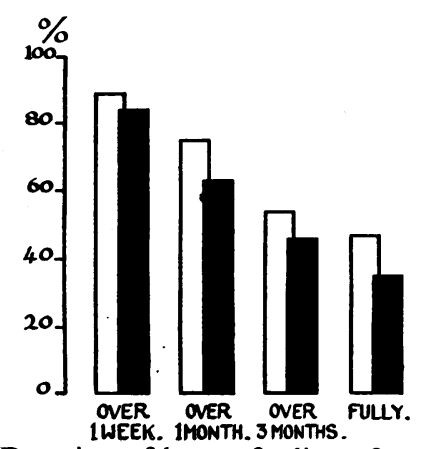

FIG. 4.-Duration of breast feeding of mature infants by primiparae and multiparae.

Outlined rectangles, multiparae.

Black ", primiparae.

Where several artificial foods had been tried, that one which had been used for the longest period was chosen for classification. The mother was asked on whose advice she gave the artificial food of choice. Where advice was given by doctor, clinic 
TABLE 6

CAUSES OF FAILURE OF BREAST FEEDING IN PREMATURE AND MATURE INFANTS

\begin{tabular}{|c|c|c|c|c|c|}
\hline \multirow{2}{*}{\multicolumn{2}{|c|}{ Cause of failure }} & \multicolumn{2}{|c|}{ Per cent. of total infants } & \multicolumn{2}{|c|}{ Per cent. of total failures } \\
\hline & & Premature & Mature & Premature & Mature \\
\hline $\begin{array}{l}\text { Insufficient lactation } \\
\text { Illness of mother } \\
\text { Prematurity ... } \\
\text { Difficulty in fixing } \\
\text { Breast abscess .. } \\
\text { Retracted nipples } \\
\text { Other causes ... }\end{array}$ & $\begin{array}{l}\because \\
\therefore \\
\therefore \\
\therefore \\
\therefore\end{array}$ & $\begin{array}{r}29 \cdot 1 \\
8 \cdot 7 \\
22 \cdot 3 \\
7 \cdot 8 \\
3 \cdot 9 \\
\frac{2 \cdot 9}{2}\end{array}$ & $\begin{array}{c}36 \cdot 2 \\
10 \cdot 3 \\
= \\
10 \cdot 3 \\
1 \cdot 7 \\
2 \cdot 9\end{array}$ & $\begin{array}{r}39 \cdot 0 \\
11 \cdot 7 \\
29 \cdot 9 \\
10 \cdot 4 \\
5 \cdot 2 \\
\overline{3 \cdot 9}\end{array}$ & $\begin{array}{l}58 \cdot 9 \\
16 \cdot 8 \\
- \\
\overline{16 \cdot 8} \\
2 \cdot 8 \\
4 \cdot 7\end{array}$ \\
\hline No. of cases & .. & 103 & 174 & 77 & 107 \\
\hline
\end{tabular}

BIRTH TO

1 WEEK.

PERCENT.

$0 \quad 20 \quad 40 \quad 60 \quad 80 \quad 100$

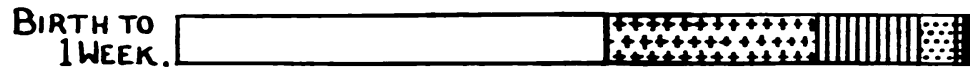

1 HEEK TO

1 MONTH.

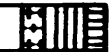

1 MONTH TO $\square$ MONTHS

PREMATURE.

3 MONTHS TO

WEANING.

1 WEEK TO

1 MONTH.

1 MONTH TO

MATURE.

3 MONTHS TO
WEANING.

Fig. 5.-Proportion of premature and mature infants still fully breast-fed at different ages, with causes of failure to breast-feed.

Still breast feeding at end of period, outlined rectangles.

Failure to breast-feed occurring during period due to:

Prematurity and difficulty in fixing, crosses.

Insufficient lactation,

Illiness of mother,

Breast abscess,

vertical lines.

Other causes,

dots.

horizontal lines.

black. 
nurse, or health visitor, it is classed as 'medical advice,' and when given by a relative (usually the grandmother), friend, or chemist, or where the mother chose the food on her own initiative, it is classed as ' non-medical.'

Fig. 6 shows the proportion of bottle-fed infants given these foods by primiparae and multiparae, and whether on medical or non-medical advice. It shows that nearly three-quarters of the multiparae fed their infants on fresh or national dried milk, compared with just over -half of the primiparae. Where medical advice was followed, these were the foods of choice, the more expensive proprietary milks and additions being given as a result of nonmedical advice, and more especially by mothers of first babies.

Of those who never succeeded in breast feeding, over three-quarters continued with the artificial food recommended in hospital, or changed only on medical advice. Where failure occurred soon after leaving hospital, before three months, 60 per cent. changed to the bottle on their own initiative or on the advice of friends, whereas when breast feeding had continued successfully for longer than three months, 65 per cent. consulted a private doctor or welfare clinic before changing to the bottle.

COMPlementary feeding. Although complementary feeding was often recommended in cases of failing lactation, in very. few cases did the mother carry this out for longer than a few weeks. Of those who never wholly fed their infants, even in hospital, a quarter attempted complementary feeding for periods longer than a week. Of those who successfully breast fed for more than three months, one-third continued with breast and bottle, most of them until weaning on to mixed diet. However, in the majority of failures which occurred between one week and three months, very few of the mothers persevered with the breast once a complementary bottle became necessary.

In short, it appears that failure in breast feeding, once it has been successfully established, most commonly occurs in the first few weeks after discharge from hospital, and certainly before the baby is three months old. The usual reason given is failing lactation, and the mother is most likely at this stage to take the baby right off the breast and substitute a bottle, commonly, in the case of a first baby, on the advice of the grandmother. If a mother succeeds in feeding her baby for longer than three months, she is usually anxious to continue, and will seek medical advice, and if possible will continue partial nursing.

A number of similar enquiries into incidence of breast feeding in different infant populations have been carried out in Great Britain, and the results of the more recent surveys are summarized in table 7 .

Vitamin supplements. Enquiry was made as to the addition of vitamins $A, D$, and $C$ to the diet. $A$ minimum adequate dose of vitamins $A$ and $D$ was taken to be one teaspoonful of Government or other cod-liver oil, six drops of halibut liver oil or adexolin, or comparable quantities of other proprietary preparations, given daily from three months to one year.

The frequency with which a source of vitamins A and $D$ was given varied with the type of feeding. Taking the whole sample, it was given in adequate dosage to 60 per cent., irregularly or in inadequate dosage to 20 per cent., and omitted altogether in 20 per cent. of infants. As will be seen from table 8, breast-fed infants approximated closely to this average. Of bottle-fed infants, nearly three-quarters of those fed on fresh milk received vitamins A and $D$, this proportion falling to less than one-half in the case of infants fed on proprietary preparations. These differences are associated with the frequency with which the various types of food were recommended by doctor or nurse, when the recommendation would be likely to be accompanied by instructions to give vitamin supplements.

A source of vitamin $C$, either in the form of fresh or concentrated orange juice, rose-hip syrup, or ascorbic acid tablets, was given more frequently than vitamins $A$ and $D$. Of the 277 children examined, 74 per cent. had received an adequate 
TAB:E 7

INCIDENCE OF BREAST FEEDING AT THREE AND SIX MONTHS ACCORDING TO VARIOUS OBSERVERS

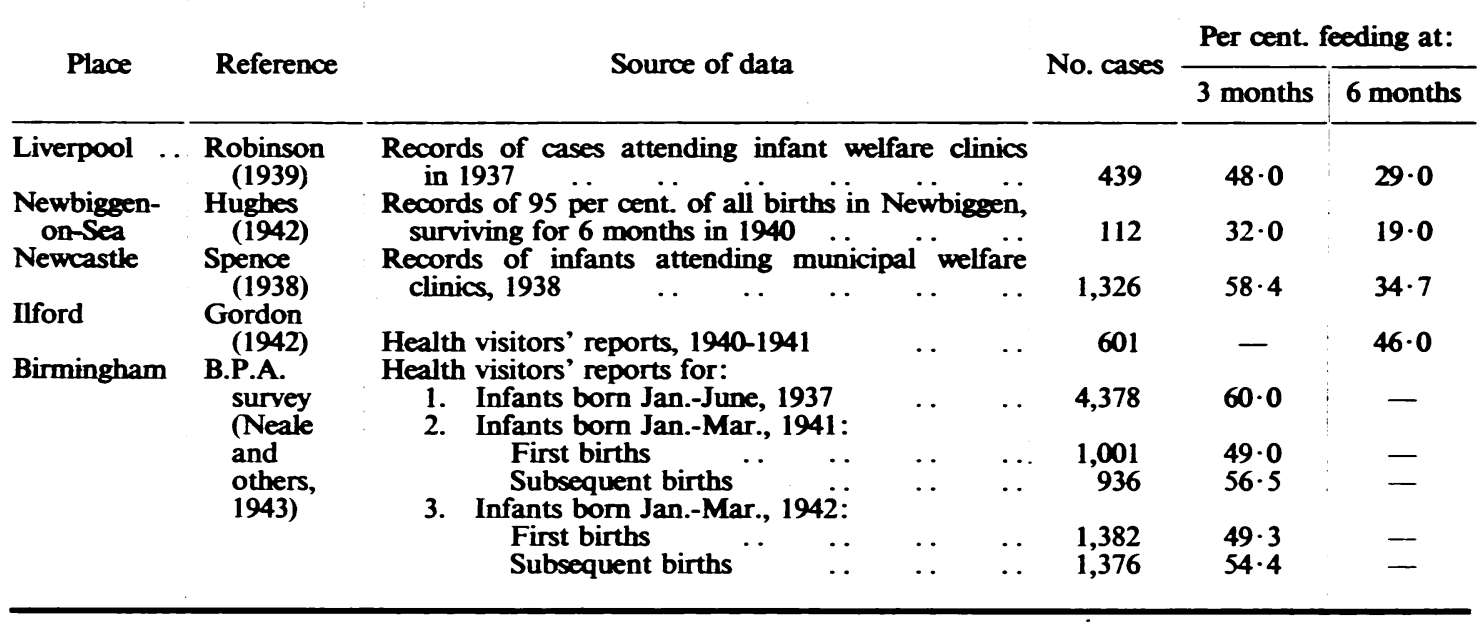

dose of vitamin $\mathrm{C}$ regularly, from the third month; 10 per cent. had been given irregular quantities, and 16 per cent. none at all.

Of those who had received adequate cod-liver oil or other vitamin D preparation, 84 per cent. were also given vitamin $C$ in some form, as were 58 per cent. of those who had had no vitamin D or only inadequate amounts.

Diphtheria immunization. Of the 277 children examined, 250 had been immunized against diphtheria. Of the remaining 27, 19 were either immunized at the follow-up clinic or the mother gave assurances that the child would be taken to the private doctor. The reasons given why immunization had not been carried out were as follows: mother had not bothered, 15; disapproval of father, 6; recurrent ill-health of child, 2; waiting for school, 2; other reasons, 2.

Of those who had attended a welfare clinic regularly, 95 per cent. had been protected, but of those who did not attend a clinic only 77 per cent.

It was also noticed that 20 per cent. of those who failed to give their children any vitamin-D preparation also failed to have them immunized; this compared with 8 per cent. non-immunization amongst the others.

Sitting, standing, walking, and talking. The mother was asked at what age the child was able to: (1) sit unsupported; (2) pull himself to the standing position, and remain standing with support; (3) walk without support across a room; (4) name numerous household objects, and be able to put two or three words together such as 'more milk,' 'all gone,' ' Johnnie's ball.' The age at which single words were first acquired was not used, because of the widely differing conceptions held by mothers as to what constitutes a 'word.'

It is realized that the mothers' answers to these

TABLE 8

PERCENTAGES OF INFANTS RECEIVING COD-LIVER OIL OR OTHER SOURCE OF VITAMIN D IN THE FIRST YEAR OF LIFE, ACCORDING TO METHOD OF FEEDING

\begin{tabular}{|c|c|c|c|c|c|c|c|}
\hline \multirow{2}{*}{\multicolumn{3}{|c|}{ Source of vitamin D }} & \multicolumn{5}{|c|}{ Method of feeding } \\
\hline & & & Breast & Fresh milk & $\begin{array}{l}\text { National dried } \\
\text { milk }\end{array}$ & $\begin{array}{c}\text { Proprietary dried } \\
\text { milk }\end{array}$ & Additions \\
\hline $\begin{array}{l}\text { Adequate } \\
\text { Inadequate } \\
\text { Nil . . }\end{array}$ & $\begin{array}{l}\cdots \\
\cdots\end{array}$ & $\begin{array}{l}\cdots \\
\cdots \\
\cdots\end{array}$ & $\begin{array}{l}59 \cdot 0 \\
19 \cdot 4 \\
21 \cdot 6\end{array}$ & $\begin{array}{l}74 \cdot 7 \\
13 \cdot 3 \\
12 \cdot 0\end{array}$ & $\begin{array}{l}54 \cdot 1 \\
21 \cdot 6 \\
24 \cdot 3\end{array}$ & $\begin{array}{l}48 \cdot 9 \\
27 \cdot 7 \\
23 \cdot 4\end{array}$ & $\begin{array}{l}52 \cdot 0 \\
28 \cdot 0 \\
20 \cdot 0\end{array}$ \\
\hline Total ... & . & $\cdots$ & $100 \cdot 0$ & $100 \cdot 0$ & $100 \cdot 0$ & $100 \cdot 0$ & $100 \cdot 0$ \\
\hline No. of cases & $\ldots$ & $\ldots$ & 93 & 75 & 37 & 47 & 25 \\
\hline
\end{tabular}


questions will not be accurate, and that there will be a natural tendency to exaggerate the prowess of their offspring. There seems no reason, however, for supposing that the mothers of premature infants would be more or less accurate in their answers than the mothers of mature infants, so for the purpose of comparing development in the two groups it is legitimate to accept the mothers' statements. Indeed, any inaccuracies by the mothers would only tend to diminish the statistical significance of any differences found, so if in spite of this, significant differences are found, then these differences can be relied upon to indicate real variations between the two groups.

Although many mothers admitted that they were not certain of the dates of sitting and standing, nearly all were most definite about the age at which the child walked, and this date is probably the most reliable. Table 9 gives the average age of sitting, standing, walking, and talking in five birth-weight groups, and this is shown graphically in fig. 7 . It will be seen that premature infants are definitely later in reaching all these 'milestones,' and the smaller the infant the more marked is the retardation. Among mature infants there is little variation with increase of birth weight; in fact the heaviest infants at birth appear to be a little later in time of standing and walking than the smaller mature infants.

The differences between the average ages at which premature and mature infants sat, stood, walked, and talked are as follows:

$$
\begin{array}{llll}
\text { Sitting } & \ldots & \ldots & \mathbf{1} \cdot 4 \text { months } \\
\text { Standing } & \ldots & \ldots & \mathbf{2 . 0} \text { months } \\
\text { Walking } & \ldots & \ldots & \mathbf{2} \cdot 0 \text { months } \\
\text { Talking } & \ldots & \ldots & \mathbf{4} \cdot 2 \text { months }
\end{array}
$$

All these differences are highly significant.

TABLE 9

AVERAGE AGE OF SITTING, STANDING, WALKING, AND TALKING, ACCORDING TO BIRTH WEIGHT

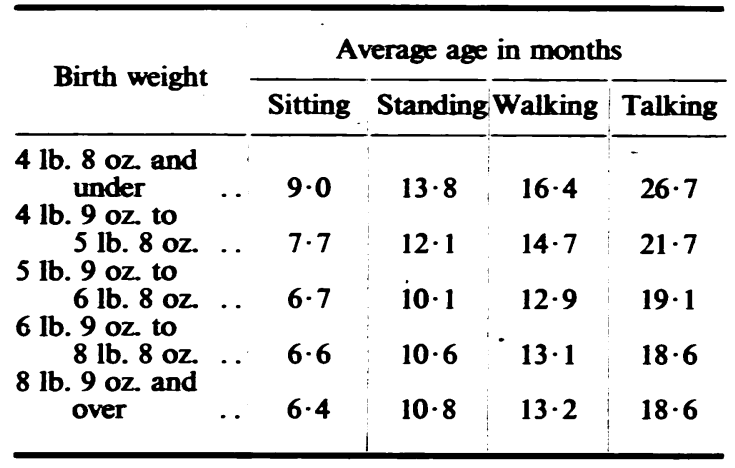

Similar figures are given by Hess and others (1934). In their group of premature infants and their full-term siblings the following differences were given between average age of sitting and walking in the two groups:

$$
\begin{aligned}
& \text { girls .. } \quad . .11 .5 \text { months } \\
& \text { boys .. } \quad . .1 .7 \text { months }
\end{aligned}
$$

They point out however that these differences would be appreciably minimized if allowance were made for degree of prematurity.

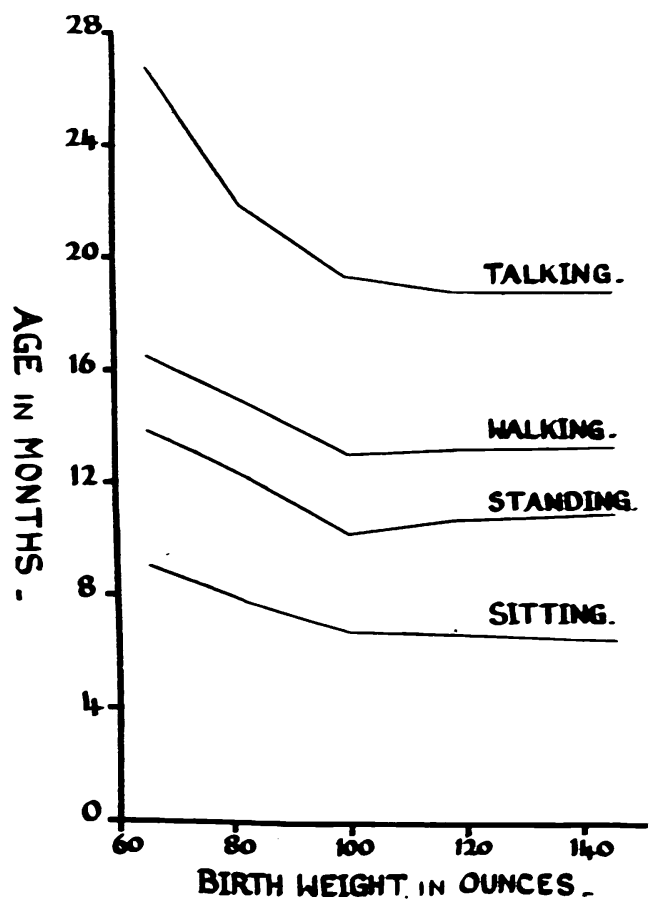

Fig. 7.-Ages at which children of different birth weight sat, stood, walked, and talked.

Morbidity rates. A full history was taken of all infections of sufficient severity to necessitate medical attention and the age at which they occurred.

The following infections were recorded: (1) measles; (2) whooping-cough; (3) bronchitis; (4) pneumonia; (5) diarrhoea and vomiting; (6) discharging ears; (7) tonsillitis; (8) others, including rubella, chicken pox, scarlet fever, diphtheria, mumps, stomatitis, gingivitis, infective hepatitis, pyelitis, and meningitis. A further group included those who had a history of recurrent bronchitis, tonsillitis, or 'chesty colds.' Children with recurrent bronchitis or tonsillitis are included once only under the appropriate heading above, as well as in this group, the age being taken as that of the first attack. 
Owing to the slightly different age composition of the premature and mature groups, and to the different ages at which the infections occurred, a method of standardizing the morbidity rates has been used. Infections in each of the two groups of children were sub-classified into six-monthly groups according to the age of the child at the time of infection. The number of children at risk in each six-monthly age period was also calculated. For instance, a child aged 18 months at the time of examination was at risk in the age groups 0-6 months, 6-12 months, and 12-18 months; a child aged 24 months would also appear in the 18-24 month group, and so on. A child aged 25 months would also count as $\frac{1}{6}$ toward the 24-30 month group, because he was at risk for only that fraction of the age period.

For each six-monthly age period the specific infection rate (number of infections/number at risk) was calculated. These figures were used to compute the morbidity rates to be expected if a standard population, of the age composition of the whole sample, had the specific rates at each age of the premature and mature children. Table 10 shows the crude and the standardized morbidity rate of the premature group as a percentage of the corresponding rates for mature children. It will be seen that the crude and standardized figures do not differ greatly. Table 10 also gives the chi-squared value for the difference between the risk of infection in the premature and mature groups. Where chi squared is 3.84 or over, the difference can be considered statistically significant, the likelihood of the difference being as big as this by chance being less than 1 in 20 . It will be seen that for all infections except measles and discharging ears, the majority of which were associated with measles, the morbidity rate for the premature children is higher, sometimes considerably so. The higher rate in the premature group is statistically significant for whooping-cough and pneumonia. The differences for bronchitis, recurrent bronchitis, sore throats and 'chesty colds,' and tonsillitis, though not significant individually, become so when takep together. The premature group also shows a greater number of cases of diarrhoea, but the difference from the mature group is not big enough to be significant.

It is difficult to see why measles should be so much higher in the mature group. One possible explanation is that there are a greater number of first births and only children in the premature group, thus lessening their risk of contracting measles from older siblings. If this were so one might expect to find a higher incidence of whooping-cough also in the mature group, whereas the observed difference is in the other direction. When the cases of whooping-cough were divided into those occurring in the first year of life and thereafter, it was found that 14 per cent. of the premature infants were reported as having had whooping-cough in the first twelve months of life, compared with 2 per cent. of the mature infants. The difference for whooping-cough after the age of one year was much smaller, 26 per cent. of the premature group, and 22 per cent. of the mature. In the first year of life it is notoriously difficult to diagnose whooping-cough from a persistent bronchitis or pneumonitis. It seems probable that a proportion at any rate of the excess cases of whooping-cough in the first year have been misdiagnosed. When all the specific fevers were taken together, excluding only cases of whoopingcough occurring in the first year, there was found to be little difference in the rate for premature and mature children, though the latter had the slightly higher rate.

TARue 10

CASES OF INFECTION OCCURRING IN PREMATURE CHILDREN COMPARED WITH MATURE CHILDREN

\begin{tabular}{|c|c|c|c|c|c|}
\hline \multirow{3}{*}{ Infection } & \multicolumn{2}{|c|}{ No. of cases } & \multirow{2}{*}{\multicolumn{2}{|c|}{$\begin{array}{l}\text { Rate in premature } \\
\text { children, taking } \\
\text { mature rate as } 100\end{array}$}} & \multirow{3}{*}{$\begin{array}{c}\text { Chi } \\
\text { squared }\end{array}$} \\
\hline & \multirow{2}{*}{ Premature } & \multirow{2}{*}{ Mature } & & & \\
\hline & & & Crude & Standardized & \\
\hline \multirow{4}{*}{$\begin{array}{l}\text { Measles .. } \\
\text { Whooping- } \\
\text { cough .. } \\
\text { Bronchitis } \\
\text { Pheumonia } \\
\text { Diarrhoea } \\
\text { Discharg- } \\
\text { ing ears } \\
\text { Tonsillitis } \\
\text { Others . } \\
\text { Recurrent } \\
\text { bronchitis }\end{array}$} & 35 & 52 & 65 & 63 & $5 \cdot 36$ \\
\hline & $\begin{array}{l}41 \\
25 \\
12 \\
12\end{array}$ & $\begin{array}{r}42 \\
38 \\
3 \\
13\end{array}$ & $\begin{array}{l}163 \\
110 \\
668 \\
154\end{array}$ & $\begin{array}{l}158 \\
109 \\
686 \\
152\end{array}$ & $\begin{array}{r}7 \cdot 21 \\
0 \cdot 17 \\
12 \cdot 24 \\
1 \cdot 30\end{array}$ \\
\hline & $\begin{array}{r}5 \\
10 \\
23\end{array}$ & $\begin{array}{r}12 \\
8 \\
40\end{array}$ & $\begin{array}{r}69 \\
208 \\
128\end{array}$ & $\begin{array}{r}64 \\
207 \\
124\end{array}$ & $\begin{array}{l}0.41 \\
2 \cdot 68 \\
0.98\end{array}$ \\
\hline & 17 & 18 & 157 & & $2 \cdot 10$ \\
\hline $\begin{array}{l}\text { No of } \\
\text { children }\end{array}$ & 103 & 174 & & & \\
\hline
\end{tabular}

Fig. 8 shows specifis morbidity rates for premature and mature children, in the first and second years of life respectively. During the first year of life the premature group show a much higher incidence of every infection except measles. In the second year rates for the two groups are very similar.

One may conclude from the above findings that there appears to be no marked difference in the liability of prematurely born or full-term children to contract the specific fevers of childhood, when likelihood of exposure to infection is taken into account. The larger number of cases of diarrhoea occurring in the premature group is found only in the first year of life, and is probably associated with the higher incidence of bottle feeding in this group, and possibly a lowered resistance in the early months. As regards respiratory and nasopharyngeal infections the premature children appear to be definitely more susceptible, especially in the first year of life.

These findings seem to be in agreement with the little that has been written about morbidity rates in prematurely born children. Hess and others (1934) found that the incidence of common contagious diseases of childhood did not differ in premature and full-term children, though there seemed to be a more frequent occurrence of respiratory infections, especially 'frequent colds' and pneumonia, in the premature group. Capper (1928) also found a 
docreased resistance to infection, especially of the respiratory tract, in prematurely born children, chiefly in the first year of life.

Physical examimation. The children were examined stripped to the waist, but the height and weight recordings were taken in light indoor clothes.

The following points were noted for every child: (1) height; (2) weight; (3) teeth-number present, number carious, whether any had been extracted, and for what reason; (4) tonsils, whether enlarged or infected; (5) cervical glands, whether palpable; (6) postural defects of the trunk or lower limbs; (7) signs of rickets; (8) any other abnormalities. In addition an estimate was made of the child's general condition. All the examinations were made by one observer, the same standards being used throughout.

TEETH. The percentage of children with no carious teeth present, and who had had none extracted because of decay, was found to be: prematurely born children, $72 \cdot 5$ per cent.; full-term children, 80.1 per cent. This difference is not statistically significant, the chi-squared value being 2.06.

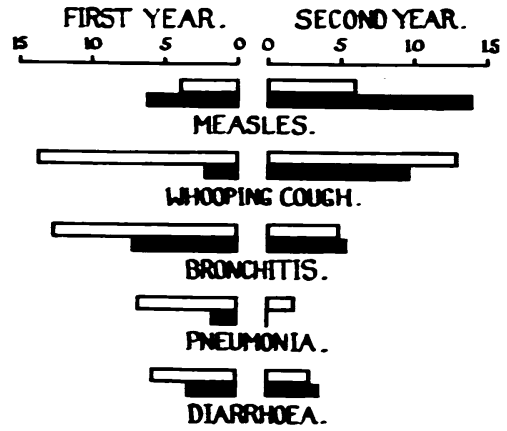

FiG. 8.- Relative morbidity rates for premature and mature children in the first and second years of life.

Scak $=$ number of cases per 100 children at risk.

NASOPHARYNGEAL INFECTION AND CERVICAL ADENris. Mere enlargement of the tonsils was not taken to be a sign of tonsillar infection. All cases classified as having a nasopharyngeal infection showed obviously infected tonsils, or a chronic nasal discharge, or both. Nearly all these cases also showed marked enlargement of the cervical glands. In most cases of glandular enlargement without obvious nasopharyngeal infection there was a history of sore throats or recurrent colds. In two cases the cervical adenitis was considered to be tubercular, and these cases have not been included in table 11, which shows the incidence of nasopharyngeal infection and cervical adenitis in premature and full-term children. As will be seen, in spite of the higher incidence of acute tonsillitis and recurrent sore throat recorded in the histories of the premature group, little difference was found between them and the mature group on examination. A slightly larger number of prematurely born children had had tonsils removed.

Rickets. Very few cases of gross rickets were seen in either group. Of the premature children, 2.0 per cent., and of the mature children 4.7 per cent. showed signs of old rickets of a moderate or severe degree, that is, showing obvious enlargement of osteochondral junctions, and epiphyses of wrist and ankle. The larger number of cases in the mature group is probably accounted for by the lower percentage receiving an adequate supply of cod-liver oil, or other vitamin D preparation, during the first year of life.

Grooving and flaring of the lower ribs, without any other sign of rickets, was noted in 19.6 per cent. of the premature children, and in 16.7 per cent. of the mature children, but this is not considered to be a reliable sign of rickets and it may occur with any type of respiratory embarrassment, such as chronic bronchitis or asthma.

TABLE 11

INCIDENCE OF NASOPHARYNGEAL INFECTION AND CERVICAL ADENITIS IN PREMATURE AND FULL-TERM CHILDREN

\begin{tabular}{|c|c|c|c|}
\hline \multirow[b]{2}{*}{ Birth weight } & & \multicolumn{2}{|c|}{ Percentage showing: } \\
\hline & & $\begin{array}{l}\text { Nasopharyngeal } \\
\text { infection }\end{array}$ & $\begin{array}{l}\text { Cervical } \\
\text { adenitis }\end{array}$ \\
\hline $\begin{array}{l}\text { Premature } \\
\text { Mature . . }\end{array}$ & & $\begin{array}{l}5 \cdot 0 \\
4 \cdot 3\end{array}$ & $\begin{array}{l}18 \cdot 6 \\
25 \cdot 9\end{array}$ \\
\hline
\end{tabular}

General condmon. The children were classified in three groups according to the following criteria:

1. Good. In these cases the child appeared to be of normal height and weight for age, and in a good state of nutrition. No obvious abnormalities were found on examination, and the mother stated that the child enjoyed good health, had made a complete recovery from such illnesses as had occurred, and was active and alive in general behaviour. Enlargement of the tonsils with slight enlargement of the cervical glands was not considered serious enough to remove a child from this category.

2. Poor. These children showed one or more of the following signs: obvious malnutrition, some gross pathological condition affecting general health (such as chronic bronchitis, congenital heart disease, gross nasopharyngeal infection); a history of constant ill health. Typically the mother would say that the child was always ailing, acquired infection easily and made a slow recovery from such infections, had a poor appetite, tired easily, and had no 'life.'

3. Fair. In between these two extremes came the children who did not measure up to the standards of group 1, and yet whose condition was not so bad as to be classed as poor. 
TAME 12

GENERAL CONDITION ACCORDING TO WEIGHT AT BIRTH

\begin{tabular}{|c|c|c|c|c|c|c|}
\hline \multirow{2}{*}{$\begin{array}{l}\text { General } \\
\text { condition }\end{array}$} & \multicolumn{6}{|c|}{ Birth weight } \\
\hline & & $\begin{array}{l}41 \mathrm{~b} .8 \mathrm{oz} \\
\text { and under } \\
\text { Per cent. }\end{array}$ & $\begin{array}{l}4 \mathrm{lb} .9 \mathrm{oz} \\
\text { to } \\
5 \mathrm{lb} .8 \mathrm{oz} \\
\text { Pa cent. }\end{array}$ & $\begin{array}{l}5 \mathrm{lb} .9 \mathrm{oz} \\
\text { to } \\
6 \mathrm{lb} .8 \mathrm{oz} \\
\text { Per cent. }\end{array}$ & $\begin{array}{c}6 \mathrm{lb} .9 \mathrm{oz} . \\
\text { to } \\
8 \mathrm{Ib} .8 \mathrm{oz} \\
\text { Per cent. }\end{array}$ & $\begin{array}{l}8 \mathrm{lb} .9 \mathrm{oz} \\
\text { and over } \\
\text { Per cent. }\end{array}$ \\
\hline $\begin{array}{l}\text { Poor } \\
\text { Fair .. } \\
\text { Good }\end{array}$ & $\begin{array}{l}\cdots \\
\cdots\end{array}$ & $\begin{array}{l}20 \cdot 0 \\
28 \cdot 0 \\
52 \cdot 0\end{array}$ & $\begin{array}{l}16 \cdot 9 \\
42 \cdot 9 \\
40 \cdot 2\end{array}$ & $\begin{array}{r}3 \cdot 0 \\
48 \cdot 4 \\
48 \cdot 4\end{array}$ & $\begin{array}{r}3 \cdot 5 \\
32 \cdot 5 \\
64 \cdot 0\end{array}$ & $\begin{array}{r}\overline{4 \cdot 3} \\
95 \cdot 7\end{array}$ \\
\hline Total & $\cdots$ & $100 \cdot 0$ & $100 \cdot 0$ & $100 \cdot 0$ & $100 \cdot 0$ & $100 \cdot 0$ \\
\hline No. of cases & . & 25 & $\pi$ & 33 & 114 & 23 \\
\hline
\end{tabular}

Table 12 shows the proportion of cases falling into each category according to their weight at birth. It will be seen that with increasing weight at birth the proportion of children classified as poor falls steadily, with a corresponding increase in those classified as good. Of those who weighed $4.5 \mathrm{lb}$. or less at birth, 20 per cent. were considered to be in poor general health, while at the other extreme, of those whose birth weight was over $8.5 \mathrm{lb}$. 96 per cent. reached the highest standard. These differences according to birth weight are highly significant. The chi-squared value is $38 \cdot 1$, and the odds against this occurring by chance are more than 130,000 to one.

HegGH AND WEIGHT. In considering height and weight according to weight at birth, the children have been divided into five birth weight groups: $4 \mathrm{lb} .8 \mathrm{oz}$. and under

$4 \mathrm{lb} .9 \mathrm{oz}$. to $5 \mathrm{lb} .8 \mathrm{oz}$.

$5 \mathrm{lb} .9 \mathrm{oz}$ to $6 \mathrm{lb} .8 \mathrm{oz}$.

$6 \mathrm{lb} .9 \mathrm{oz}$ to $8 \mathrm{lb} .8 \mathrm{oz}$.

$8 \mathrm{lb} .9 \mathrm{oz}$. and over

For each birth weight group the regression equation has been calculated of weight on age, and height on age; this being the equation to the straight line which best describes the association between these characteristics. The equations are set out in table 13 and graphically in figs. 9 and 10 . From these equations one can calculate what would be the average height and weight at any age for each birth weight group as shown in tables 14 and 15 . These tables also give the average weight and height of children of the same ages, as compiled from Holt's figures by Sheldon (1946). It has been assumed that the relation between weight or height and age can adequately be expressed by a straight line, whereas in actual fact the rate of growth is greater at the earliest ages, but for the purpose of comparing growth in different birth-weight groups this can legitimately be ignored. Fig. 9 shows that at any given age, average weight rises steadily with increasing birth weight. At two years there is a difference of $5 \mathrm{lb}$. in average weight between the smallest and the largest birth-weight groups; the difference is $6 \mathrm{lb}$. at three years and $7 \mathrm{lb}$. at four years.
Fig. 10 demonstrates the same trend as regards height, though the differences between birth-weight groups are not nearly so marked.

TABUE 13

REGRESSION EQUATIONS FOR HEIGHT AND WEIGHT ON AGE IN DIFFERENT BIRTH WEIGHT GROUPS

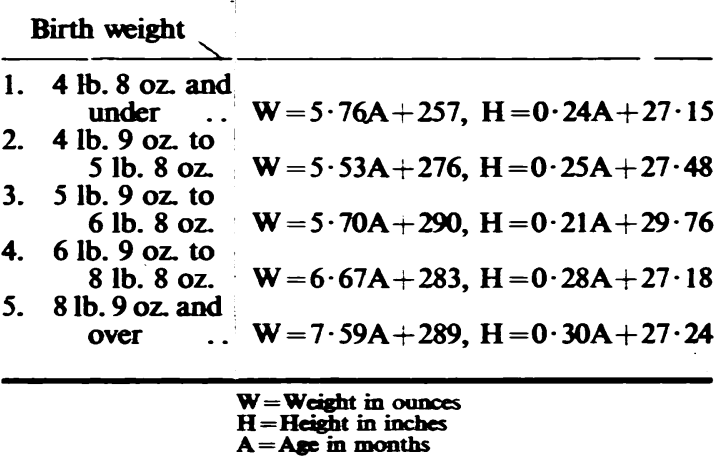

Very few surveys have been carried out in this country on the progress and development of the prematurely-born child, after the first year of life, but numerous observers on the Continent and in the United States come to very different conclusions as to the progress of these children. For instance Capper (1928) after a detailed study of 103 prematurely-born children between the ages of one and seventeen years writes, "The fate of immature children is not enviable; almost one half of them die during the first year of life. Of those that remain alive the majority are physically as well as mentally underdeveloped.' Whereas Hess and others (1934), from an equally careful study of 250 premature infants between one and seven years, concluded that by the age of four years the prematurely-born child had caught up in every respect with the mental and physical development of the full-term child.

The discrepancies seem to be due largely to different methods of selecting the sample, and whether a comparable control group of full-term children was included in the study. Capper selected his cases from 23,000 hospital records. 613 were picked who seemed from their medical history to have been prematurely born, though only 437 were verified by checking the birth weights with the maternity departments concerned. From this number he obtained 103 children for re-examination. It is obvious that in the method of selection there was a bias in favour of including those with a history of early difficulties, and all the cases had for some reason passed through hospital. These 
TABLE 14

AVERAGE WEIGHT AT DIFFERENT AGES, ACCORDING TO WEIGHT AT BIRTH, CALCULATED FROM THE REGRESSION EQUATIONS

\begin{tabular}{|c|c|c|c|}
\hline \multirow{2}{*}{ Birth weight } & \multicolumn{3}{|c|}{ Average weight in lbs. } \\
\hline & 2 years & 3 years & 4 years \\
\hline $\begin{array}{l}4 \mathrm{lb} .8 \mathrm{oz} \text {. and under } \\
4 \mathrm{lb} .9 \mathrm{oz} \text {. to } 5 \mathrm{lb} .8 \mathrm{oz} . \\
5 \mathrm{lb} .9 \mathrm{oz} \text {. to } 6 \mathrm{lb} .8 \mathrm{oz} . \\
6 \mathrm{lb} .9 \mathrm{oz} \text {. to } 8 \mathrm{lb} .8 \mathrm{oz} . \\
8 \mathrm{lb} .9 \mathrm{oz} \text {. and over }\end{array}$ & $\begin{array}{l}24 \cdot 7 \\
25 \cdot 5 \\
26 \cdot 7 \\
27 \cdot 7 \\
29 \cdot 5\end{array}$ & $\begin{array}{l}29 \cdot 0 \\
29 \cdot 7 \\
31 \cdot 0 \\
32 \cdot 7 \\
35 \cdot 1\end{array}$ & $\begin{array}{l}33 \cdot 3 \\
33 \cdot 8 \\
35 \cdot 2 \\
38 \cdot 1 \\
40 \cdot 8\end{array}$ \\
\hline $\begin{array}{l}\text { Standard for normal chil- } \\
\text { dren, adapted from Holt } \\
\text { and McIntosh (1940) }\end{array}$ & $28 \cdot 0$ & $33 \cdot 0$ & $37 \cdot 0$ \\
\hline
\end{tabular}

children were compared, not with a control group of full-term infants selected from the same records, but with accepted standards for normal healthy children. It is hardly surprising that the premature group compared unfavourably.

Those observers who have compared a random sample of premature infants with various accepted standards of normality, usually agree that prematurely-born children show to a greater or lesser degree a lower average height and weight. Von Sydow (1936) examined a series of ninety-eight premature children between the ages of three and nine years, and found a certain degree of underdevelopment as compared with the general population. Brander $(1938,1941)$ followed up a series of nearly $\mathbf{4 0 0}$ premature infants until the end of school age, and came to the same conclusion. On the

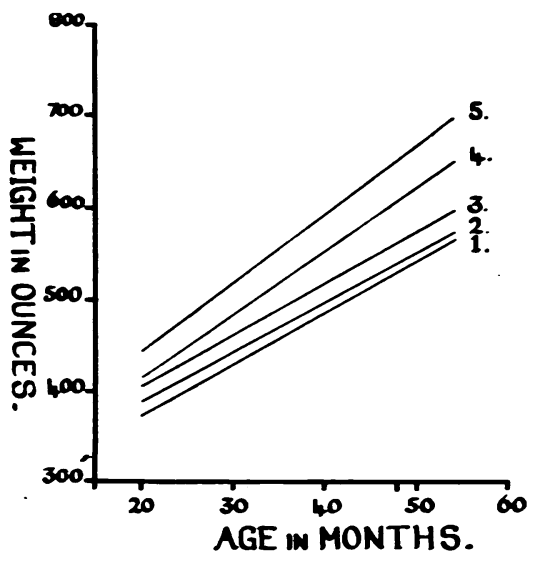

FIG. 9.- Regression lines showing relation between weight and age for five birth weight groups.

(1) $4 \mathrm{lb} .8 \mathrm{oz}$ and under; (2) $4 \mathrm{lb} .9 \mathrm{oz}$. to $5 \mathrm{lb} .8 \mathrm{oz}$; (3) $5 \mathrm{lb} .9 \mathrm{oz}$. to $6 \mathrm{lb} .8 \mathrm{oz}$; (4) $6 \mathrm{lb} .9 \mathrm{oz}$. to $8 \mathrm{lb} .8 \mathrm{oz}$; (5) $8 \mathrm{lb} .9 \mathrm{oz}$. and over.
TABLE 15

AVERAGE HEIGHT AT DIFFERENT AGES ACCORDING TO WEIGHT AT BIRTH, CALCULATED FROM THE REGRESSION EQUATIONS

\begin{tabular}{|c|c|c|c|}
\hline \multirow{2}{*}{ Birth weight } & \multicolumn{3}{|c|}{ Average height in inches } \\
\hline & 2 years & 3 years & 4 years \\
\hline $\begin{array}{l}4 \mathrm{lb} .8 \mathrm{oz} \text {. and under } \\
4 \mathrm{lb} .9 \mathrm{oz} \text { to } 5 \mathrm{lb} .8 \mathrm{oz} \text {. } \\
5 \mathrm{lb} .9 \mathrm{oz} \text { to } 6 \mathrm{lb} .8 \mathrm{oz} \text {. } \\
6 \mathrm{lb} .9 \mathrm{oz} \text { to } 8 \mathrm{lb} .8 \mathrm{oz} \text {. } \\
8 \mathrm{lb} .9 \mathrm{oz} \text { and over }\end{array}$ & $\begin{array}{l}32 \cdot 9 \\
33 \cdot 2 \\
34 \cdot 8 \\
33 \cdot 9 \\
34 \cdot 4\end{array}$ & $\begin{array}{l}35 \cdot 8 \\
36 \cdot 5 \\
37 \cdot 3 \\
37 \cdot 3 \\
38 \cdot 0\end{array}$ & $\begin{array}{l}38 \cdot 7 \\
39 \cdot 5 \\
39 \cdot 8 \\
40 \cdot 6 \\
41 \cdot 6\end{array}$ \\
\hline $\begin{array}{l}\text { Standard for normal chil- } \\
\text { dren adapted from Hol } \\
\text { and McIntosh (1940) }\end{array}$ & $33 \cdot 0$ & $37 \cdot 0$ & $40 \cdot 0$ \\
\hline
\end{tabular}

other hand Hess and others (1934) and Schultze (1939), using as their control group brothers and sisters of the premature infants in question, both concluded that there was no fundamental difference as regards height, weight, or general development after the first few years of life. It should be noted that Hess's group of premature children had been carefully supervised by doctors and social workers throughout the period under review, as had a group quoted by Levine and Gordon (1942), which also showed no striking difference from a comparable full-term group.

In this country Asher (1946) recently examined a series of 217 prematurely-born children between the ages of one and six years and found them to be below average weight at all ages compared with standard figures quoted by Holt and McIntosh (1940). Illingworth (1939) compared a random

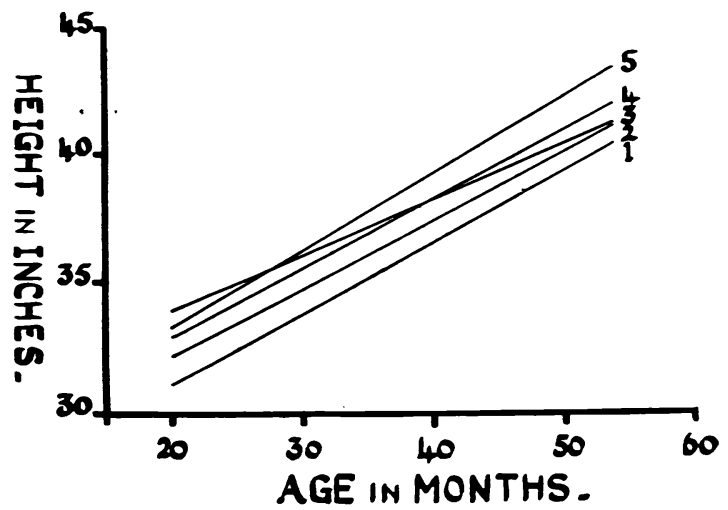

Fig. 10.-Regression lines showing relation between height and age for five birth weight groups.

(1) $4 \mathrm{lb} .8 \mathrm{oz}$ and under; (2) $4 \mathrm{lb} .9 \mathrm{oz}$. to $5 \mathrm{lb} .8 \mathrm{oz}$; (3) $5 \mathrm{lb} .9$ oz. to $6 \mathrm{lb} .8 \mathrm{oz}$; (4) $6 \mathrm{lb} .9 \mathrm{oz}$. to $8 \mathrm{lb} .8 \mathrm{oz}$.; (5) $8 \mathrm{lb} .9 \mathrm{oz}$. and over. 
sample of 152 children between the ages of one and eleven years who weighed $5.5 \mathrm{lb}$. or less at birth, with a similar group weighing $8.5 \mathrm{lb}$. or more at birth, all of them being children attending the out-patient department of Great Ormond Street Hospital, London. He found that the premature children were under weight as compared with the control group.

In interpreting these different findings the most important question to decide is whether the fact of premature birth alone places the child under a permanent handicap, or whether it is rather that the unfavourable factors which acted on the mother, causing the premature delivery, continue to act on the child after birth. There is ample evidence to support the theory that premature birth is closely associated with bad economic and social conditions. The Royal College of Obstetricians and Gynaecologists suggest in their report on the National Maternity Service (1944) that prematurity is largely due to defective maternal diet. This was corroborated by Cameron and Graham (1944), who examined the diets of one hundred mothers of premature and one hundred mothers of mature infants, and found the food intake to be qualitatively and quantitatively better in the latter group. Baird (1945) found the incidence of prematurity among women of poor social class in hospital to be twice as high as that among private patients in a nursing home. The Registrar General for England and Wales (1931) found that deaths of infants attributed to premature birth increased as one descends the social scale, and were about twice as common among babies of unskilled labourers as among those of Social Class 1. Woolf (1947) showed that neonatal death rates and death rates from congenital causes, of which prematurity forms the most important single cause, are very highly correlated with poverty indices. It seems reasonable to suppose that these economic handicaps would continue to act on the premature infant after birth, and this supposition is strengthened by the fact that where brothers and sisters from the same environment are used as the control group very little difference is found after the first few years of life. Equally, where good post-natal conditions exist and adequate supervision, the premature infants surviving the first year of life quickly caught up with comparable full-term children. It is hoped to amplify this theme in a further paper, in which the social background of a group of premature and mature infants will be studied and compared.

Behaviour problems. Every mother was questioned as to the general behaviour of her child, and whether there were any problems in social adaptation or habit formation. Questions were asked about feeding and sleeping habits, bladder and bowel control, attitude to children, parents, and other adults. No attempt was made to obtain detailed case histories, only obvious behaviour disorders being recorded.

Twenty-four out of 102 mothers of prematurely born children ( 23 per cent.), and 25 of 170 mothers of full-term children (15 per cent.) reported behaviour problems. Feeding problems were by far the commonest complaint, and these have been considered separately.

In most other cases the mother stated that the child was generally difficult to manage, was ' out of hand,' exhibited temper if thwarted, was overdependent on his parents, and had difficulties in his relations with other children or adults. In a minority of cases there was one outstanding symptom or symptom complex which was considered to be functional in origin. For example, one child suffered for two years from extreme constipation which was entirely cured by treatment at a child guidance clinic. A boy with crippling asthma always had an attack following parental quarrels, which were frequent. Another had frequent attacks of cyclical vomiting provoked by excitement, and particularly by his failing to get his own way. In this case the child lived in crowded conditions with seven adults, including two grandmothers, and was the centre of attention of the whole household.

In most cases it was obvious that the mother had little control over the child, who was being mismanaged at home. Many suffered from bad housing conditions or from having to live with grandparents, where authority was divided between the mother and grandmother. The majority were difficult to examine and needed much reassurance before permitting themselves to be undressed. In a few cases examination was impossible because of screaming, kicking, and other manifestations of temper.

FeEDING PRoblems. Here the mother stated that the child had a poor appetite and had to be coaxed to eat by various devices. In all cases, to a greater or lesser extent, meals had become a struggle between the child and his parents.

It was noticeable that the general health of children with feeding problems was inferior to those without such difficulties, and therefore a comparison was made between the incidence of feeding disorders in children of good, fair, and poor general health, for both premature and mature children.

The results are shown in table 16. A striking difference is seen between the incidence of feeding problems in those in poor and good health for both premature and mature children. Among the premature children the difference between the group classified as in poor general health and that classified as 'fair' is highly significant, the chi-squared value being 20.81; the difference between 'fair' and ' good' is also significant, with a chi-squared value of 4.77. In the mature group the two 
similar comparisons also show significant differences, here the chi-squared values are $18 \cdot 70$ and $4 \cdot 16$ respectively.

Although both premature and mature groups show the same trend, it will be seen that the incidence of feeding problems in the former is higher in every health category. The differences between the premature and mature rates in each sub-group when taken together are statistically significant, a combined probability test giving a $t$ value of $3: 125$. A $t$ value of 2.0 would be significant according to the accepted standard of a probability of 0.05 . It appears, therefore, that though there is a positive association between feeding problems and poor health irrespective of birth weight, there is also a significantly higher rate among prematurely born children as compared with full-term children, quite apart from their state of health.

TABLE 16

PERCENTAGE OF PREMATURE AND MATURE CHILDREN WITH FEEDING PROBLEMS ACCORDING TO THEIR GENERAL HEALTH

\begin{tabular}{|c|c|c|c|c|c|}
\hline & & \multicolumn{4}{|c|}{ General health } \\
\hline & & Poor & Fair & Good & Total \\
\hline $\begin{array}{l}\text { Premature } \\
\text { Mature . . } \\
\text { Total . . } \\
\text { No. in group }\end{array}$ & $\begin{array}{l}\cdots \\
\cdots \\
\cdots\end{array}$ & $\begin{array}{l}83 \cdot 3 \\
60 \cdot 0 \\
78 \cdot 3 \\
23\end{array}$ & $\begin{array}{l}20 \cdot 0 \\
3 \cdot 7 \\
10 \cdot 6 \\
94\end{array}$ & $\frac{4 \cdot 6}{155}$ & $\begin{array}{r}24.5 \\
2.9\end{array}$ \\
\hline
\end{tabular}

OTHER BEHAViOUR PROBLeMs. Table 17 shows the incidence of other behaviour disorders in premature and mature children according to their state of general health.

Here the difference between premature and mature is much smaller and is not statistically significant, the chi-squared value being only $1 \cdot 77$.

However, the incidence of behaviour disorder is over twice as high in the 'poor' health group as in the 'fair,' and three and a half times the rate among those in good general health. The difference between the 'poor' and 'fair 'groups is statistically significant (chi-squared value $=5 \cdot 37$ ); the difference between the 'fair' and 'good' groups is not. significant (chi-squared value $=1 \cdot 45$ ), but the difference is in the same direction and very suggestive.

Summing up these findings one may say that both feeding problems and other behaviour disorders as a whole appear to be more common in children whose general health is poor, and that as regards feeding problems there is a preponderance of cases among prematurely born children. No conclusions are drawn as to whether the behaviour disorder results from the poor health or vice versa.

Hess et. al. (1934), in their study of premature children and their full-term siblings, observed that 'prematurely born children more frequently evidence dependency reactions in relation to their mothers, are somewhat less adequate in their earliest social responses, and display temper more frequently.'

\section{Summary}

This paper comprises Part 4 of a series of studies in prematurity based on births in the Simpson Memorial Pavilion, Edinburgh, during the years 1943-1945 inclusive. It is divided into two sections: (1) a comparison of the medical history of surviving premature and mature infants before discharge from hospital; and (2) an account of a follow-up examination of a sample of prematurely-born children, and a control group of full-term children.

TABLE 17

PERCENTAGE OF PREMATURE AND MATURE CHILDREN WITH BEHAVIOUR DISORDERS (OTHER THAN FEEDING PROBLEMS), ACCORDING TO THEIR GENERAL HEALTH

\begin{tabular}{|c|c|c|c|c|c|}
\hline & & & Gener & health & \\
\hline & & Poor & Fair & Good & Total \\
\hline $\begin{array}{l}\text { Premature } \\
\text { Mature .. } \\
\text { Total . . } \\
\text { No. in group }\end{array}$ & $\begin{array}{l}\cdots \\
\cdots \\
\cdots\end{array}$ & $\begin{array}{l}38 \cdot 9 \\
40 \cdot 0 \\
39 \cdot 1 \\
23\end{array}$ & $\begin{array}{l}25 \cdot 0 \\
11 \cdot 1 \\
17 \cdot 0 \\
94\end{array}$ & $\begin{array}{r}6 \cdot 8 \\
13 \cdot 5 \\
11 \cdot 6 \\
115\end{array}$ & $\begin{array}{l}19 \cdot 6 \\
13 \cdot 5\end{array}$ \\
\hline
\end{tabular}

\section{Section 1: Progress in Hospital}

Infection rates in the first ten days of life were considered. Infants of $3.5 \mathrm{lb}$. or under at birth had a much higher rate of septic skin infection and conjunctivitis than larger babies. The incidence of thrush fell steadily with increasing birth weight, this being associated most probably with increase in breast feeding. The smallest infants appeared relatively immune to gastro-enteritis, this probably being due to their isolation from the main nursery.

Comparative rates are also given for other pathological conditions occurring in infants of different birth weights.

\section{Section 2: Progress in Early Childhood}

A sample of 277 children between the ages of one-and-a-half and four-and-a-half years returned for re-examination: 103 were prematurely born, and 174 were full-term children.

The following points arising out of information given by the mother were considered:

1. Feeding in the first year. The incidence of breast feeding was found to vary with birth weight and parity. Causes of failure in breast feeding, and the artificial foods chosen by different types of mothers, are discussed. 
2. Administration of vitamin supplements.

3. Diphtheria immunization.

4. Milestones in development. A significant difference was found between the ages at which premature and mature infants sat, stood, walked, and talked. The smaller the infant, the more marked was the retardation. Among mature infants there was little variation with increase of birth weight.

5. Morbidity rates. No marked difference was found between the liability of premature and mature children to contract the specific fevers of childhood. Prematurely-born children showed a significantly higher incidence of nasopharyngeal and respiratory infection, this being especially marked in the first year of life.

6. Behaviour disorders. Twenty-three per cent. of the premature, and 15 per cent. of the full-term children were reported as having behaviour problems. Feeding problems were the most common. These, as well as behaviour disorders in general, were positively associated with poor health. There was a preponderance of feeding problems amongst the premature group.

The following findings were made from the physical examination:

1. No significant difference was found between premature and full-term children in the incidence of dental caries, nasopharyngeal infection, cervical adenitis, and rickets.

2. The children were classified as to their general condition into three groups: poor, fair, and good. With increasing birth weight the proportion of children classed as 'poor' fell steadily, from 20 per cent. in those of $4.5 \mathrm{lb}$. and under at birth, to none in those weighing over $8 \cdot 5 \mathrm{lb}$. There was a corresponding increase in those classed as ' good.' These differences are highly significant.

3. Height and weight. Regression equations were calculated of height on age and weight on age, for each of five birth-weight groups. At any given age, average weight was found to rise steadily with increasing birth weight. The same trend was observed for height, though the differences were not so striking.
The work of other observers in this field is discussed, and the suggestion is made that the differences found after the first few years of life between prematurely-born and full-term children, as regards height, weight, and general development, are due largely to environmental factors, being the same adverse conditions as originally acted on the mother to produce the premature delivery.

It is a pleasure to thank Dr. Barnet Woolf for advice on the statistical methods used; Miss E. Thomas, S.R.N., for much valuable assistance at the follow-up clinic; and Professor R. W. B. Ellis for his interest and encouragement.

\section{REFERENCES}

Asher, C. (1946). Brit. med. J.,.1, 793.

Baird, D. (1945). J. Obstet. Gynec., 52, 217, 339.

Brander, T. (1938). Finska läk.-sällsk handl., 81, 1183. (1941). Nord. Med., 9, 212.

Cameron, C. S., and Graham, S. (1944). Glasgow med. J., $142,1$.

Capper, A. (1928). Amer. J. Dis. Child., 35, 262, 443.

Drillien, C. M. (1947). J. Obstet. Gynec., 54, 300, 443, 452.

Gordon, I. (1942). Arch. Dis. Childh., 17, 139.

Henderson, J. L. (1943). Edinb. med. J., 50, 535.

Hess, J. H., Mohr, G. J., and Bartelme, P. F. (1934). The Physical and Mental Growth of Prematurely Born Children. Chicago.

Holt, L. E., and McIntosh, R. (1940). Diseases of Infancy and Childhood. New York.

Hughes, E. L. (1942). Brit. med. J., 2, 69.

Illingworth, R. S. (1939). Arch. Dis. Childh., 14, 121.

Levine, S. Z, and Gordon, H. H. (1942). Amer. J. Dis. Child., 64, 274.

Neale, A. V., Cassie, E., Braid, F., and Pierce, M. (1943). Arch. Dis. Childh., 18, 59.

Registrar General for England and Wales (1931). Decennial Supplement, Part 2A, Occupational Mortality. London.

Robinson, M. (1939). Arch. Dis. Childh., 14, 259.

Royal College of Obstetricians and Gynaecologists (1944). Report on National Maternity Service. London.

Schultze, K. W. (1939). Z. Geburtsh Gynäk., 118405. Sheldon, W. (1946). Diseases of Infancy and Childhood. London.

Spence, J. C. (1938). Brit. med. J., $2,729$.

Sydow, G. v. (1936). Upsala lakaref fohr., 42, 21.

Woolf, B. (1947). Brit. J. soc. Med., 1, 73. 